JAMP: Jurnal Adminitrasi dan Manajemen Pendidikan

Volume 1 Nomor 3 September 2018, Hal : 313-319

Tersedia Online di http://journal2.um.ac.id/index.php/jamp/

ISSN 2615-8574 (online)

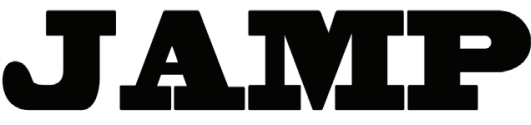

\title{
MANAJEMEN HUBUNGAN SEKOLAH DENGAN DUNIA USAHA DAN INDUSTRI DALAM MENINGKATKAN PRESTASI BELAJAR PESERTA DIDIK SEKOLAH MENENGAH VOKASIONAL
}

\author{
Isnaini Afrita Syari \\ Ali Imron \\ Imron Arifin
}

\author{
IsnainiSyari24@gmail.com \\ Universitas Negeri Malang, J1. Semarang No. 5 Malang 65145
}

\begin{abstract}
: : in this research describes the steps of cooperation, collaboration, what have been the advantages of both sides between 3 Malang with the business world and the world of industry (DUDI). This study uses qualitative methods. Qualitative research is research that intends to understand the phenomena of behavior, action, a thorough State of a subject. While this type of research is research case studies. Reasons to use a case study is a research method is focusing on a unique case of an intensive and detailed. The uniqueness of the obtained in this case is, the existence of the provision of learner achievements at the push by the agency outside the school where it is where practice learners. The results of this study, namely, the establishment of a Committee for cooperation, the kind of effort that will be selected schools, pre OJT activity, making the agreement a Memorandum of understanding, provide the best quality of learners, promotes work and responsibility, provide benefits to the industry, carry out the evaluation, the students keep a journal, compiling reports.
\end{abstract}

Keywords: school, cooperation, learning achievements

\begin{abstract}
Abstrak : Pada penelitian ini menjelaskan langkah-langkah kerjasama, bentuk kerjasama, apa yang menjadi keuntungan kedua pihak antara SMKN 3 Malang dengan dunia usaha dan dunia industri (DUDI). Penelitian ini menggunakan metode kualitatif. Penelitian kualitatif merupakan penelitian yang bermaksud untuk memahami fenomena tentang perilaku, tindakan, keadaan menyeluruh pada sebuah subjek penelitian. Sedangkan jenis penelitian yang digunakan adalah penelitian studi kasus. Alasan menggunakan studi kasus adalah metode penelitian ini memusatkan perhatian pada suatu kasus yang unik secara intensif dan rinci. Keunikan yang didapatkan pada kasus ini adalah, bekal adanya prestasi yang diraih peserta didik di dorong oleh lembaga luar sekolah dimana itu merupakan tempat praktik peserta didik. Hasil penelitian ini yaitu, pembentukan panitia kerjasama, jenis usaha yang akan dipilih sekolah, kegiatan pra OJT, membuat perjanjian Memorandum of understanding, memberikan kualitas terbaik peserta didik, mempromosikan kerja dan tanggung jawab, memberikan keuntungan kepada industri, melaksanakan evaluasi, peserta didik membuat jurnal, menyusun laporan.
\end{abstract}

Kata Kunci : hubungan sekolah dan masyarakat, teknik, kerjasama, evaluasi, kendala

Indonesia merupakan salah satu negara yang berkembang di dunia, beberapa permasalahan yang ada di dalamnya belum teratasi secara maksimal. Salah satu masalah yang berat adalah masih adanya pengangguran yang tidak hanya terjadi di Ibu kota saja tetapi di seluruh kota di Indonesia yang terkadang terjadi peningkatan bahkan penurunan. Lulusan yang lebih banyak menjadi pengangguran adalah lulusan Sekolah Menengah Kejuruan (SMK) yang mencapai 11,11 \% menurut data (Badan 
Pusat Statistik, 2016). Lulusan SMK terletak pada urutan pengangguran tertinggi. Sehingga pemerintah memberikan solusi program yang baik untuk pendidikan di Indonesia.

Pendidikan selalu berkesinambungan. Sekolah dan masyarakat merupakan lingkungan yang saling bergantung. Sekolah merupakan wadah untuk belajar sedangkan lingkungan masyarakat merupakan sarana mengaplikasikan dari proses pendidikan dan pengajaran disekolah, bagaimana belajar disekolah selalu dikaitkan dengan kegunaanya bagi peningkatan hidup dan kehidupan di masyarakat. Masyarakat merupakan partisipan untuk mendukung pendidikan. Menurut Sugian dalam Nasution (2010: 11) bahwa "manajemen adalah proses menggerakkan orang lain agar memperoleh hasil tertentu dalam rangka pencapaian tujuan yang ditentukan sebelumnya". Ketika menggerakkan orang lain, kita membutuhkan ilmu yang lebih dari cukup, bahkan lebih sulit dari sekedar hanya penyampaian secara visual. Dalam menggerakkan orang lain dengan baik pada lembaga sekolah kita memerlukan ilmu manajemen pendidikan. Menurut Imron (2003: 5), manajemen pendidikan adalah "suatu proses penataan kelembagaan pendidikan dengan terlibatnya sumber-sumber potensial, baik bersifat manusia maupun non-manusia dalam rangka mencapai tujuan utama pendidikan yang efektif dan efisien". Sumber-sumber potensial didalamnya adalah yang mendukung tercapainya tujuan sekolah. Sekolah dapat mencapai tujuan salah satunya dengan melakukan kerjasama, baik kerjasama dengan personil sekolah maupun dengan lembaga lain,

Menjalin kerjasama sebaiknya saling mendukung apa yang telah menjadi perbedaan pendapat karena tidak semua perbedaan membawa pengaruh yang buruk selama kita dapat menyikapi dengan baik. Hal tersebut perlu dilakukan agar lebih mudah menghasilkan rencana awal sesuai dengan pengertian kerjasama untuk mencapai keinginan yang maksimal atau secara allout. Memberikan bantuan juga menjadi hal yang diperlukan untuk bisa menjalin kerjasama yang lancar dan sesuai tujuan. Selain itu, perlu juga untuk menunjukkan perhatian dan niat rencana pada apa yang menjadi kesepakatan awal.

\section{METODE}

Penelitian ini menggunakan pendekatan kualitatif sebagai prosedur penelitian yang menghasilkan data deskriptif berupa kata-kata tertulis atau lisan dari orang-orang dan perilaku yang diamati dan diteliti. Peneliti memilih pendekatan kualitatif karena sesuai dengan tema yang dipilih, yaitu cenderung menggali informasi, sehingga penulis dapat mendeskripsikan fenomena yang terjadi secara menyeluruh dan mendalam. Penelitian kualitatif menurut Ulfatin (2015: 24) adalah sebagai berikut. "Penelitian yang bermaksud untuk memahami fenomena tentang apa yang dialami oleh subjek penelitian misalnya perilaku, persepsi, motivasi, tindakan, dan lain-lain, secara holistik, dan dengan cara deskriptif dalam bentuk kata-kata dan bahasa, pada suatu konteks khusus yang alamiah dan dengan memanfaatkan berbagai metode ilmiah".

Jenis penelitian yang digunakan adalah studi kasus. Menurut Sukmadinata (2013) penelitian kualitatif yang menggunakan studi kasus berarti penelitian difokuskan pada satu fenomena saja yang dipilih dan ingin dipahami secara mendalam, dengan mengabaikan fenomena-fenomena lainnya. Oleh karena itu peneliti memilih jenis penelitian studi kasus dengan tujuan untuk mengetahui secara mendalam tentang manajemen hubungan sekolah dengan dunia usaha dan industri dalam meningkatkan prestasi belajar siswa.

Kehadiran peneliti sangat penting karena peneliti berperan sebagai instrumen penelitian. Jadi peneliti harus hadir di lapangan untuk berinteraksi secara langsung dengan subjek penelitian. Kehadiran peneliti di lapangan menurut Sugiyono (2011: 306) adalah sebagai human instrument, berfungsi untuk menetapkan fokus penelitian, memilih informan sumber data, melakukan pengumpulan data, menganalisis data, menafsirkan data, dan membuat kesimpulan atas apa yang ditemukan. Sebelum melakukan penelitian, peneliti melakukan studi pendahuluan untuk mengetahui kondisi objek penelitian secara umum dan menyeluruh.

Cara mengadakan studi pendahuluan yaitu dengan mencari data pendukung dari berbagai sumber pustaka, bertemu dan bertanya kepada para ahli dan orang yang mengetahui sumber informasi dan 
datang secara langsung ke lokasi penelitian yang telah ditentukan. Studi pendahuluan dilakukan untuk menentukan langkah penelitian dan mencari atau mengembangkan ide tentang masalah yang akan diteliti.

Kehadiran peneliti di lokasi penelitian sudah diketahui oleh kepala SMK Negeri 3 Malang . Pada hari Senin, tanggal 30 Januari 2017 peneliti menanyakan prosedur melakukan penelitian di SMK Negeri 3 Malang kemudian Peneliti datang ke fakultas untuk membuat surat izin pada hari Jumat tanggal 3 Februari 2017 untuk meminta izin melaksanakan penelitian. Pada tanggal 13 Februari 2017 peneliti selesai membuat surat pengantar dari fakultas dan, mengantar ke bagian tata usaha SMK Negeri 3 Malang, ternyata di arahkan untuk menyerahkan surat ke bagian wakil kepala sekolah. Kemudian dipertemukan dengan bagian penelitian sekolah, dan diarahkan untuk menemui Ibu Rizal Leni G.S.SSt. Par, MM. selaku wakil kepala sekolah hubungan sekolah dan masyarakat juga sebagai tenaga pengajar jurusan perhotelan.kemudian tanggal 16 Februari peneliti melakukan wawancara pertama mengenai manajemen hubungan sekolah dengan dunia usaha dan industri. Peneliti hadir di sekolah pada jam istirahat yaitu pukul 10.00 WIB dikarenakan pada jam tersebut supaya tidak mengganggu proses pembelajaran yang berlangsung. Wawancara berjalan dengan lancar dan narasumber juga memberikan informasi yang sesuai. Kemudian pada tanggal 13 Maret 2017 peneliti kembali ke sekolah untuk menggali informasi untuk melakukan wawancara kedua mengenai kerjasama dunia usaha dan industri. Dan terakhir melakukan wawancara ketiga untuk menggali informasi dalam penelitian pendahuluan dengan Ibu Rizal Leni adalah 22 Maret 2017 di ruang wakil kepala sekolah. Berikut merupakan tabel rekap kehadiran peneliti di SMK Negeri 3 Malang.

\section{HASIL}

Kegiatan kerjasama pada dunia pendidikan, tidak terlepas dari ilmu manajemen pendidikan dimana terdapat fungsi manajemen yakni POAC (Planning, Organizing, Actuating, Controlling). Setiap kegiatan di lembaga formal maupun tidak, di lembaga pendidikan ataupun tidak tetap memerlukan perencanaan. Perencanaan yang dilakukan tidak hanya satu pemikiran dari satu orang tetapi dari beberapa orang yang terlibat di dalamnya. Begitu juga dengan perencanaan kerjasama sekolah, di SMK Negeri 3 Malang ini perencanaanya tidak hanya sekedar bekerja sama tetapi memikirkan akibat yang terjadi dari perencanaan tersebut. Kerjasama dengan dunia usaha dan industri bukanlah hal yang mudah seperti membalikkan dua telapak tangan tetapi hal yang cukup sulit, maka harus membutuhkan pihak - pihak yang dapat dipercaya kemampuanya. Salah satu yang terlibat besar dalam kerjasama ini adalah tugas wakil kepala sekolah pada bagian Hubungan Sekolah dan Masyarakat (HUMAS).

Perencanaan yang penting adalah berkoordinasi dengan wali murid. Wali murid atau orang tua peserta didik merupakan salah satu hal yang sangat krusial untuk kelancaran kegiatan ini, mulai dari bermusyawarah mengenai ijin pemberangkatan, tempat praktik, biaya, juga kesepakatan lain jika diperlukan mengenai kegiatan praktik kerja lapangan ini dengan nama On The Job Training (OJT).

Pelaksanaan PKL atau OJT ini, salah satu kegiatan yang dipersiapan sekolah adalah kegiatan Pra OJT. Kegiatan ini dilaksanakan selama satu semester sebelum pelaksanaan OJT selama satu semester juga dengan waktu OJT 4 (empat) hingga 5 (lima) bulan. Peserta pra OJT sesuai dengan kebijakan jurusan masing-masing. Minimal peserta pra OJT berjumlah 2 (dua) orang dilakukan secara bergilir sesuai dengan nomor presensi. Selama kegiatan pra OJT, peserta didik wajib memberikan bukti kegiatan berupa jurnal yang diisi dengan dibubuhi tanda tangan pembimbing pra OJT.

Kegiatan pra OJT dipersiapkan sekolah untuk mematangkan kemampuan praktik peserta didik di dunia industri melihat tantangan di dunia industri semakin berat sehingga program sekolah fokus untuk meningkatkan skill peserta didik. Kerjasama antara kedua lembaga yang menangani keilmuan yang sama sudah biasa terlihat semisal dunia pendidikan dengan dunia pendidikan, dunia kesehatan dengan dunia kesehatan yang saling berhubungan. Tetapi jika dilihat dunia pendidikan dan dunia industri merupakan dua lembaga dengan bidang yang berbeda sehingga segala peraturan dan bentuk kerjasama sedikit berbeda. Sekolah memilih bekerja sama dengan dunia industri karena dunia industri juga memberikan feedback yang baik kepada sekolah. 
Salah satu contoh feedback yang di dapat tersebut adalah prestasi yang di peroleh sekolah. Pada saat pembelajaran di kelas mereka hanya merasa sebagai peserta didik yang tidak begitu besar tugasnya hanya praktik yang tidak lama dalam kegiatan pembelajaran, sehingga peserta didik merasa masih biasa saja dan sedikit memudahkan tugas-tugas, tetapi ketika di praktik di dunia industri mereka sadar bahwa tugas tersebut berat dan berbeda dengan di sekolah.

SMK Negeri 3 Malang sering meraih prestasi LKS (Lomba Kompetensi Siswa) yang merupakan salah satu lomba yang meningkatkan persaingan sehat antara sekolah vokasi di Indonesia yang umumnya menyebut LKS. Kegiatan ini merupakan kegiatan yang hampir sama dengan kegiatan olimpiade tingkat nasional.

Kompetensi lomba siswa diadaka setiap tahun. Ada beberapa peserta didik yang sering membawa nama SMK Negeri 3 Malang pada lomba bergengsi ini. Prestasi tersebut didapatkan dengan kerja keras, juga bimbingan dari bapak atau Ibu guru SMK Negeri 3 Malang jga pengalaman dari PKL yang memberikan ilmu berbeda dengan apa yang telah di dapatkan di sekolah sebagai ilmu tambahan dari peserta PKL untuk menambah skill nya. Prestasi tersebut didapatkan dengan kerja keras, juga bimbingan dari bapak atau Ibu guru SMK Negeri 3 Malang juga pengalaman dari PKL yang memberikan Ilmu berbeda dengan apa yang telah di dapatkan di sekolah sebagai ilmu tambahan dari peserta PKL untuk menambah skill nya.

Meskipun hanya bentuk moril itu merupakan penghargaan dalam bentuk sederhana yang memberikan bukti bahwa adanya kerjasama dengan hasil yang memuaskan antara dunia usaha dan industri dengan sekolah.

Peserta didik meraih prestasi karena merasa ada tanggung jawab yang besar yang diberikan oleh sekolah dan mereka dipercaya untuk menyelesaikan tugas itu untuk mewakili sekolah tercinta dengan membawa almamater kebanggaan. Tentunya, DUDI sangat membantu sekolah untuk mewujudkan itu karena bagaimanapun sekolah menengah kejuruan tetap membutuhkan kerjasama yang baik dengan pihak luar. Tempat PKL selalu memberikan pelayanan yang baik kepada peserta didik yang sedang praktik di tempat usahanya.

\section{PEMBAHASAN}

Kegiatan kerjasama di SMK Negeri 3 Malang, sesuai dengan keilmuan administrasi pendidikan jika dilihat dari hasil telaah. Pihak yang terlibat tidak pernah melaksanakan tugas diluar dari kebutuhan sekolah. Kerjasama selalu dilakukan saling membantu antara tugas guru satu dengan guru lain yang menjadi panitia PKL di setiap tahunya. Jika salah satu proses pembelajaran ini dilaksanakan untuk mengantarkan peserta didik untuk meraih prestasi, maka persiapan ini tentunya dilaksanakan sebaikbaiknya. Agar tidak mengecewakan wali peserta didik, dalam hal ini merupakan orang tua yang berhak tahu perkembangan anaknya di sekolah dan tentunya menyerahkan kepada sekolah untuk diarahkan untuk menjadi lulusan yang di terima di kalangan industri nantinya.

"Sekolah dalam menjalankan kerjasama tentunya harus memperhatikan visi dan misinya sehingga kegiatan yang akan dilaksanakan dalam kerjasama sekolah dengan masyarakat memiliki kontribusi besar terhadap pencapaian tujuan dan sasaran sekolah" dalam Benty dan gunawan (2015: 7). Karena, visi misi merupakan pedoman apa yang akan dilakukan oleh sekolah dalam melaksanakan kerja sama dengan dunia usaha dan industri. Visi dan misi akan berjalan dengan adanya prinsip yang cukup kuat di setiap lembaga.

Kegiatan awal perencanaan pelaksanaan Pra OJT dan OJT adalah dengan mengundang wali peserta didik untuk hadir diundang oleh kepala sekolah untuk memusyawarahkan kegiatan tersebut. Sekolah menginformasikan bahwa kegiatan dilaksanakan selama 6 bulan tersebut membutuhkan dukungan wali peserta didik juga. Kegiatan ini tidak dapat berjalan jika hanya pihak sekolah saja yang mempersiapkan. Sekolah bertugas mempersiapkan teknis dari kegiatan tersebut, maka orang tua peserta didik membantu 
mempersiapkan mental menggambarkan bagaimana dunia kerja, juga membesarkan hati anaknya jika nanti ada masalah atau pun hal lain yang membutuhkan dukungan orang tua.

Pertemuan pihak sekolah dan orang tua diadakan untuk menjelaskan tempat praktik anaknya, serta memberikan surat ijin boleh melaksanakan PKL diluar sekolah. Tanpa dipungkiri ada juga beberapa orang tua yang tidak mengijinkan anaknya untuk melaksanakan kegiatan KPL diluar sekolah dikarenakan tidak mau jauh dengan anaknya atau karena hal lain yang menjadikan mereka memiliki alasan yang kuat. Tidak menjadi masalah bagi pihak sekolah karena guna pertemuan sebelum pemberangkatan karena telah ada tawar menawar antara keduanya.

Pada tempat praktik, peserta didik harus memberikan kemampuan terbaiknya untuk membuktikkan kepada industri bahwa dapat melaksanakan peranya sebagai pegawai atau karyawan di tempat industrinya tersebut. Setiap peserta didik mendapatkan tempat sesuai dengan jurusanya masing-masing. Bahkan dalam kerjanya mereka juga ditempatkan sesuai dengan kemampuan yang dipelajari di sekolah sebelumnya. Tempat industri memberikan pengalaman yang berbeda tentunya dari sekolah, apa yang telah diberikan oleh guru merupakan teori yang menjadi bekal peserta didik untuk mengeksplore saat praktik kerja di kelas 11 (sebelas). Sehingga jika ada perbedaan tetapi yang dimaksudkan sama, maka industri hanya meluruskan sesuai dengan SOP dari industri itu sendiri.

Ada beberapa prinsip yang perlu ditekankan dalam kerjasama. Prinsip yang perlu patuhi supaya bisa menghasilkan sesuai apa yang diimpikan lembaga. Prinsip kerjasama diantaranya adalah transparansi yang harus dijaga dengan keilmuanya. Memiliki awal yang jelas untuk menjembatani kepentingan setiap pihak yang bekerjasama seperti halnya pengertian kerjasama untuk mencapai tujuan bersama. Prinsip lain yang harus dijaga dalam bekerjasama adalah efisiensi dan juga efektifitas kerjasama. Saat kerjasama tidak lagi efektif tentu tidak dapat memberikan keuntungan bagi sekolah maupun bagi industri itu sendiri. Selain itu, dalam bekerjasama semua pihak juga harus berpegang pada prinsip keterbukaan. Agar kepercayaan tetap terjalin diantara dua pihak.

Hoy dan Miskel dalam Maisyaroh (2003:124-125) membuat ilustrasi komponen suatu lembaga pendidikan yang berada di luar, dalam penjelasan ilustrasi disimpulkan bahwa penyelenggaraan sekolah memiliki hubungan dengan lembaga yang lain. Hubungan sekolah dengan masyarakat salah satunya dengan perusahaan atau lembaga luar sekolah dalam bentuk penempatan praktik kerja peserta didik dan penyerapan peserta didik setelah lulus sekolah. Dunia industri luar sekolah merupakan tempat bagi peserta didik dalam melakukan praktik kerja industri, dan sekolah dapat mengembangkan kurikulumnya yang disesuaikan dengan dunia kerja. Setelah lulus, diharapkan peserta didik dapat bekerja di suatu lembaga industri yang diharapkan, khususnya hal ini merupakan pengenalan sekolah menengah kejuruan atau vokasional.

Ditinjau dari kepentingan hubungan sekolah yang diantaranya untuk mempertahankan kehidupan sekolah adalah untuk meningkatkan kualitas pendidikan di sekolah yang bersangkutan, mempermudah proses belajar bagi peserta didik dan mengajar bagi pendidik yang memperoleh dukungan dan bantuan dari masyarakat mengenai hal yang diperlukan dalam pengembangan dan pelaksanaan program sekolah. Kelangsungan kehidupan sekolah didapatkan tidak hanya di dalam lembaga sekolah itu sendiri, kelangsungan tersebut adalah berkesinambungan untuk masa depan peserta didik pada jangka waktu pendek maupun jangka yang panjang. dalam Yulitasari (2015) menjelaskan bahwa tugas dan tanggungjawab kepala humas yaitu memimpin koordinasi internal humas, memberikan arahan dan nasehat kepada unit terhadap kegiatan yang menyimpang dari Visi dan Misi organisasi, menghadiri rapat-rapat yang dilaksanakan oleh yayasan, melaporkan kegiatan dan keuangan kepada ketua yayasan dan pihak luar yang terkait, serta bertanggungjawab terhadap tugas dan kegiatan humas.Tugas dan tanggungjawab pengelola humas yaitu menyusun program kerja humas, menyelenggarakan rapat koordinasi humas dengan bagian terkait, melaksanakan program kerja humas, mengkoordinasikan pelaksanaan evaluasi program kerja bulanan, melaporkan hasil pelaksanaan program kerja kepada kepala sekolah. Kegiatan humas memang sebaiknya tersusun sesuai dengan kebutuhan sekolah. Sehingga tidak ada kegiatan yang tertinggal didalamnya. 
Kerjasama adalah jalan keluar untuk mencapai tujuan tertentu dengan cara yang lebih memudahkan suatu lembaga pendidikan formal maupun tidak. Tujuan tersebut misalkan salah satunya adalah prestasi. Prestasi belajar adalah suatu capaian yang didapatkan oleh seseorang dalam usaha yang dilakukan dan usaha itu telah berhasil secara maksimal sesuai dengan harapan individu. kegunaan prestasi belajar berbeda-beda, bergantung kepada ahli dan bidangnya masing masing diantaranya sebagai feedback atau timbal balik bagi pendidik dalam mengajar materi, untuk keperluan menganalisa, juga untuk keperluan bimbingan dan penyuluhan. Selain itu, juga untuk keperluan seleksi dalam menentukan jurusan. Dalam Setyowati (2015) Pelaksanaan Hubungan Sekolah dengan Masyarakat Pelaksanaan hubungan sekolah dengan masyarakat merupakan kegiatan untuk penggunaan sarana dan prasarana, pengkomunikasian kegiatan humas, pengorganisasian kegiatan humas, pelaksanaan teknik humas, pemantauan kegiatan, dan kerjasama sekolah dengan pihak internal maupun eksternal sekolah.

Wujud dari kerjasama adalah: (a) Hubungan sekolah dengan orang tau murid harus dipelihara sebaik-baiknya, (b) Untuk mewujudkan hubungan tersebut, perlu dibentuk satu panitia pemeliharaan sekolah yang terdiri atas beberapa orang tua murid, dan (c) Susunan dan kewajiban panitia pembantu pemeliharaan sekolah ditetapkan oleh Mendikbud. Hubungan sekolah dengan masyarakat serta hubungan sekolah dengan orang tua murid, pada hakikatnya adalah sarana yang cukup mempunyai peran menentukan dalam usaha pembinaan, pertumbuhan, dan pengembangan murid-murid di sekolah. Oleh karena itu, hubungan tersebut perlu dibina, dibangun dan dipelihara sebaik-baiknya karena merupakan jembatan saling pengertian sehingga mereka dapat berpartisipasi secara positif dan dapat memberikan dukungan moral material secara ikhlas. Menurut Subroto (2004: 65) dalam Ratri melakukan kerjasama agar tercapai yaitu dengan keberhasilan yang maksimal yang artinya tercapai tujuan orang tua dan masyarakat ditempuh dari berbagai macam bidang baik dari proses pembelajaran di sekolah maupun melalui berbagai macam kegiatan di luar sekolah. Masyarakat merupakan sumber yang menyediakan peserta didik, guru, sarana dan prasarana npenyelenggaraan sekolah dan peserta dalam proses pendidikan yang mengikuti dan turut mempengaruhi proses pendidikan di sekolah seperti yang tertera dalam gambar berikut.

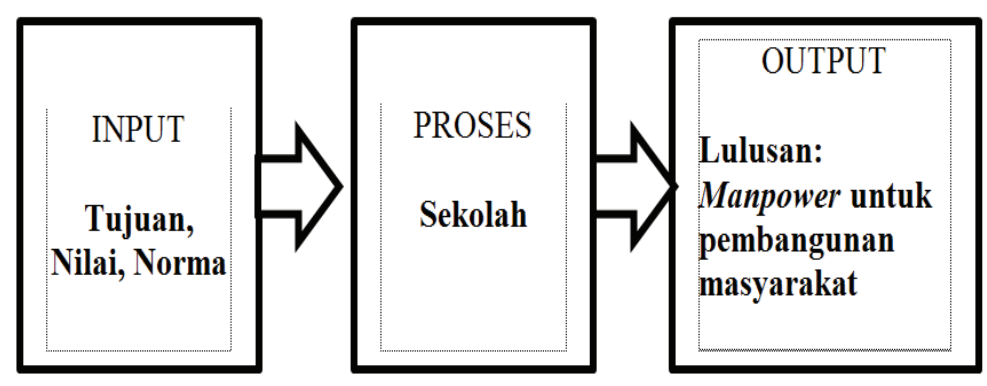

Gambar 1.Sistem Hubungan Sekolah dengan Masyarakat

Bukan hanya itu, ketika ada peserta didik yang skill nya sangat baik mereka dipercaya untuk mewakili sekolah dalam mengikuti ajang yang bergengsi di kalangan sekolah kejuruan atau vokasional yaitu lomba kompetensi siswa. SMK Negeri 3 Malang telah banyak meraih kejuaraan mulai dari tingkat kota hingga nasional. Prestasi ini begitu membanggakan bagi sekolah dan tentunya bagi orang tua peserta didik. Kerjasama yang baik juga akan mengasilkan sesuatu yang membanggakan.

Prestasi belajar sangat di dukung beberapa faktor, diantaranya keluarga, sekolah, dan masyarakat. "Masyarakat terdiri atas berbagai kelompok manusia yang tinggal di salah satu daerah, menunjukkan kesatuan berdasarkan pengalaman bersama berupa budaya, memiliki sejumlah lembaga yang melayani kepentingan masyarakat, serta mempunyai kesadaran akan kesatuan tempat tinggal dan bila perlu dapat melaksanakan secara bersama". (Nasution: 2004)

Sudah menjadi ketentuan jika masyarakat mempunyai pengaruh besar terhadap belajar peserta didik. Karena dalam masyarakat, peserta didik berinteraksi dengan lingkungannya, dan interaksi yang kurang tepat sering kali terjadi sehingga dapat memberi pengaruh peserta didik dalam belajarnya. Dan diantara pengaruh tersebut merupakan kegiatan siswa dalam masyarakat, teman satu lingkungan, media masa, yang merupakan bentuk kehidupan masyarakat. 


\section{KESIMPULAN}

Bahwa kerjasama yang baik merupakan kerjasama yang tidak memberi kerugian dan dilakukan secara efektif dan efisien. Kerjasama sekolah dengan dunia usaha dan industri memberikan keuntungan bagi masing-masing lembaga untuk mengembangkan sumberdaya yang bersifat soft skill maupun hard skill. Pelaksanaan kerjasama sekolah vokasional dengan industri dapat dilihat melalui pengembangan hubungan kerjasama antara sekolah vokasional dengan industri dilaksanakan oleh sekolah melalui pihak yang berpengalaman mengenai kehumasan.

Hubungan kerjasama dikembangkan dengan prinsip saling membantu antara kedua pihak, khususnya dalam pengembangan sumber daya manusia dan peningkatan kemampuan didalam suatu lembaga. Pengembangan tersebut dapat dimulai dari pihak sekolah. Harus memiliki daftar nama industri yang terpercaya disekitarnya. Bukan hanya kepala sekolah, wali peserta didik juga harus dapat membantu mengatur sarana, personal dan jadwal kegiatan perkembangan hubungan kerjasama antara keduanya. Sebaiknya terlebih dulu menyusun MoU (Memorandum of Understanding) secara formal dalam bentuk tertulis untuk kesepakatan kerjasama.

Strategi dalam kerjasama juga dibutuhkan dalam melaksanakan PKL sekolah ini, karena kerjasama ini tidak hanya kebutuhan sekolah saja tetapi juga kebutuhan industri. Terdapat hubungan simbiosis mutualisme seperti kerjasama yang saling menguntungkan antara sekolah dan juga industri

\section{DAFTAR RUJUKAN}

Benty,Noor dan Gunawan,I.2015.Manajemen Hubungan Sekolah dan Masyarakat.Malang: Universitas Negeri Malang.

Imron, dkk. 2003. Manajemen Pendidikan. Malang: Universitas Negeri Malang.

Maisyaroh.2004.Hubungan Masyarakat.Malang: Fakultas Ilmu Pendidikan Universitas Negeri Malang.

Nasution,M.2010.Manajemen Humas di Lembaga Pendidikan.Malang: Universitas Muhammadiyah Malang Press. Nasution. 2004. Sosiologi Pendidikan.Jakarta: Bumi Aksara.

Ulfatin, N. 2015. Metode Penelitian Kualitatif di Bidang Pendidikan: Teori dan Aplikasinya. Malang: Media Nusa Kreatif.

Ratri, Y. Kerjasama Sekolah Dengan Masyarakat Dalam Manajemen Peningkatan Mutu Di Sekolah Dasar Se Kecamatan Pakualaman Yogyakarta. http://staffnew.uny.ac.id/upload/132304798/penelitian/kerjasamasekolah.pdf diakses pada 6 Juli 2018.

Setyowati, S.2015. Manajemen Hubungan Sekolah Dengan Masyarakat Di Taman Kanak-Kanak Se- Kecamatan Mlati, Kabupaten Sleman. http://journal.student.uny.ac.id/ojs/ojs/index.php/fipmp/article/viewFile/97/92 diakses pada 6 Juli 2018

Sugiyono. 2011. Metode Penelitian Pendidikan. Bandung: Alfabeta.

Sukmadinata, N. S. 2013. Metode Penelitian Pendidikan. Bandung: PT Remaja Rosdakarya.

Yulitasari, E. 2015. Pelaksanaan Hubungan Sekolah Dan Masyarakat Di Sekolah Berbasis Pesantren (Studi Kasus Di Smp Ar-Rohmah Putri Malang)http://ap.fip.um.ac.id/wp-content/uploads/2015/04/effa.pdf diakses pada 25 Juli 2018. 